\begin{tabular}{lc}
\hline & ANNALES \\
& UNIVERSITATIS MARIAE CURIE-SKŁODOWSKA \\
LOL. V & SECTIO N \\
\hline
\end{tabular}

ISSN: 2451-0491 - e-ISSN: 2543-9340 - CC-BY 4.0 • DOI: 10.17951/en.2020.5.251-264

\title{
Poezja i malarstwo o starości kobiet - wiersze Anny Świrszczyńskiej w dialogu z wybranymi obrazami
}

Poetry and Painting about the Old Age of Women - Poems by Anna Świrszczyńska in Dialogue with Selected Paintings

\author{
Matgorzata Gajak-Toczek \\ Uniwersytet Łódzki. Wydział Filologiczny \\ ul. Pomorska 171/173, 90-236 Łódź \\ mgajaktoczek@o2.pl \\ https://orcid.org/0000-0002-9774-887X
}

\begin{abstract}
The aim of the article is to look at the identity of an old woman on the example of works by Anna Świrszczyńska, which were compared with selected paintings. It was emphasized that the specificity of the poet's artistic creation, her way of presenting a woman's point of view to all phenomena and feelings, did not lead to the negation of male reality, but constituted its complement. The intended interdisciplinary nature of discourse is justified by the belief that the diversity of linguistic message multiplies the strength of art's influence, empathically orientates recipients to the uniqueness as well as the individuality of the subject's existential relationship with the world in works of art.
\end{abstract}

Keywords: Anna Świrszczyńska; old woman; works of art

Abstrakt. Celem artykułu jest ogląd tożsamości starej kobiety na przykładzie utworów Anny Świrszczyńskiej, które porównano z wybranymi pracami malarskimi. Podkreślono, że specyfika kreacji artystycznej poetki, jej sposób prezentacji kobiecego punktu widzenia na wszelkie zjawiska i uczucia, nie prowadziła do negacji rzeczywistości męskiej, lecz stanowiła jej uzupełnienie. 
Zamierzona interdyscyplinarność dyskursu ma uzasadnienie w przekonaniu, że różnorodność językowego przekazu zwielokrotnia siłę oddziaływania sztuki oraz empatycznie orientuje odbiorców na niepowtarzalność i jednostkowość doświadczenia egzystencjalnej relacji podmiotu ze światem w dziełach sztuki.

Słowa kluczowe: Anna Świrszczyńska; stara kobieta; dzieła sztuki

\section{WPROWADZENIE}

Zmiany struktury wieku ludności - „siwienie” społeczeństwa polskiego i europejskiego - to jeden z poważniejszych problemów, przynoszący rozmaite implikacje (m.in. ekonomiczne, społeczno-kulturowe), z którym mierzą się lub będą musiały zmierzyć się obecne i następne pokolenia. Kwestie starzenia się populacji są często przywoływane w przekazie medialnym, przeżywają swój renesans również w publikacjach naukowych, artystycznych i popularnych. Ważne miejsce w dyskursie na temat wieku matuzalemowego i sposobów radzenia sobie z jego konsekwencjami przypada szeroko pojętej edukacji formalnej i nieformalnej. Literackie i kulturowe obrazy starości warto poddać refleksji w ramach lekcji języka polskiego' ${ }^{1}$.

Sztuka, w tym szeroko eksplikowana na "godzinach polskiego"2 literatura, daje niejedną sposobność akcentowania doświadczeń seniorów. Pozwala choćby uobecnić późną dorosłość w świadomości zbiorowej jako czas, w którym królują mądrość, doświadczenie i wyrosła zeń wiedza o prawidłach ludzkiego bytu. Człowiecze istnienie literatura ukazuje pod postacią metafory podróży ukoronowanej realizacją wartości uniwersalnych, ważnych w rozwoju osobniczym każdego przedstawiciela gatunku homo sapiens. Do dyskursu społecznego wprowadza także obrazy starości smutnej, naznaczonej wstydliwie skrywanym bólem, cierpieniem, fizycznymi ułomnościami, utrudniającymi sprawne funkcjonowanie w codzienności, a niekiedy skazującymi na konieczność korzystania z opieki innych. Hasło memento mori stanowi kolejny istotny element w rejestrze refleksji senilnej. W kreowanych wizjach próbuje się z jednej strony uchwycić wspólne doświadczeniom staruszków właściwości, których identyfikacja pozwoli lepiej zrozumieć istotę wieku matuzalemowego tyleż od strony korporalnej, co psychicznej, z drugiej zaś ze względu na heterogeniczność

1 Ze względu na ramy artykułu rezygnuję z dyskusji na temat implikacji, które niesie za sobą formuła „kształcenie polonistyczne” (szerzej zob. Kłakówna 2016: 95-112).

2 Nawiązuję w tym miejscu do pracy Zenona Urygi (1996). 
populacji ludzi starych kładzie się nacisk na indywidualizm dostępnych im przeżyć biograficznych ${ }^{3}$.

W przekazie edukacyjnym zasadniczo podejmuje się problemy starości męskiej (Tadeusz Różewicz, Jarosław Iwaszkiewicz, Zbigniew Herbert, Czesław Miłosz). Nawet pobieżny ogląd spisu lektur w dokumentach programowych potwierdza powyższą tezę̧. Zasadne zatem jest wprowadzenie do lekcyjnej rzeczywistości różnych strategii konceptualizacji starości kobiet. Decyzja ta wydaje się tym istotniejsza, że społeczne stereotypy dotyczące późnej dorosłości są najczęściej nieprzyjazne przedstawicielkom płci pięknej (zob. na ten temat: Stefaniak-Hrycko 2006: 202-210). Starość dla kobiety bywa momentem wykluczenia, odrzucenia, utratą akceptacji i możliwości wyznaczenia sobie drogi odmiennej od społecznie nakazywanych konwenansów. Zmianę tej sytuacji umożliwia bycie starą poetką, co potwierdza poezja Anny Świrszczyńskiej, Wisławy Szymborskiej, Urszuli Kozioł, Julii Hartwig, Krystyny Miłobędzkiej i Adrianny Szymańskiej. Poetki przyjmują role, które wyrastają ponad przeciętne reguły trwania, m.in. kapłanki bądź prowokatorki, mistyczki lub ironistki obnażającej twarde prawa jednostkowej i zbiorowej egzystencji. Stara kobieta, pisząc, wyłamuje się prostym regułom zbiorowego trwania, a zajmując miejsca niejako na obrzeżach wspólnotowego istnienia, zyskuje autonomię twórczą i egzystencjalną.

Celem niniejszego artykułu jest ogląd tożsamości starej kobiety, starej baby (zob. Kwiatkowski 1995: 373-376), możliwej do wywiedzenia z wybranych utworów Anny Świrszczyńskiej5. Dlaczego spośród wielu w kontekście interesującej nas problematyki proponuję przyszłym polonistom refleksję nad jej dziełem i wybranymi pracami malarskimi? Na tę decyzję wpłynęło kilka czynników. Po pierwsze, specyfika kreacji artystycznej Świrszczyńskiej. Składa się na nią choćby przekonanie pisarki, że prezentacja kobiecego punktu widzenia ${ }^{6}$ na wszelkie zjawiska i uczucia, duchowość i cielesność, cierpienie i ekstazę, życie i śmierć nie musi prowadzić do negacji rzeczywistości męskiej, lecz stanowi jej uzupełnienie (por. Wiśniewski 1986: 163). Po drugie, w pełni zgadzam się

3 Problem ten poruszyłam w wielu artykułach (zob. Gajak-Toczek 2012: 339; Gajak-Toczek 2013: 76-82; Gajak-Toczek 2018: 161-172; Gajak-Toczek i Gala-Milczarek 2015: 51-61; Gajak-Toczek i Gala-Milczarek 2017: 209-226).

4 Spostrzeżenie to dotyczy także studentów (por. Olszański 2012: 36-62).

5 Autorka doczekała się trzech monografii (zob. Stapkiewicz 2014; Stawowy 2004; Miłosz 1996). Należy dodać, że Czesław Miłosz położył nacisk na biografizm i autentyzm oraz na skomentowanie relacji rodzinnej autorki, ale przede wszystkim próbował zrozumieć jej sensualizm i kobiecość. W świadomości zbiorowej została zapamiętana jako autorka tomów późnych, z lat 70. XX wieku: Jestem baba (1972), Budowałam barykade (1974), Szczéśliwa jak psi ogon (1978).

6 Dominacja takiej postawy widoczna jest już w debiutanckim zbiorze poetki Wiersze i proza (1936). Tom wysoko ocenili ówcześni krytycy: Ludwik Fryde, Kazimierz Wyka, Józef Czechowicz. 
z Renatą Ingbrant (2018: 263), że „ostentacyjna demonstracja widzenia wszystkiego z perspektywy podmiotu, który jest kobietą i identyfikuje się z innymi kobietami (u Świrszczyńskiej »my« to kobiety), ma na celu radykalną rewizję kobiecości oraz rewaluację kobiecego doświadczenia w literaturze", w tym oczywiście - doświadczenia starości. Kobiecość artystki, co należy podkreślić, jest głównie manifestacją „pewnej formy człowieczeństwa, człowieczeństwa aktywnego i zdobywczego" (Kwiatkowski 1971: 102).

Zamierzona interdyscyplinarność dyskursu ma uzasadnienie w przekonaniu, że różnorodność językowego przekazu zwielokrotnia siłę oddziaływania sztuki, empatycznie orientuje odbiorców na niepowtarzalność oraz jednostkowość doświadczenia egzystencjalnej relacji podmiotu ze światem w dziełach sztuki ${ }^{7}$. Stanowi realizację jednego z wielu etapów edukacji „dla” i „ku” starości. Zależy mi przy tym nie tyle na sporządzeniu kompletnego opisu, co w ramach niewielkiego artykułu skazane byłoby z góry na porażkę, ile na wytyczeniu pewnego pola możliwych działań. Temu podporządkowany jest dobór przykładów werbalizujących czy kreujących współczesną narrację o kobiecej starości, wyznaczających możliwe sposoby jej konceptualizacji, jakie pojawiły się podczas zajęć przygotowujących studentów Uniwersytetu Łódzkiego do zawodu nauczyciela.

\section{PÓŹNA DOROSŁOŚĆ}

Uniwersalna perspektywa wierszy Świrszczyńskiej łączy się przede wszystkim ze śmiercią jako końcem ziemskiej wędrówki. Rozmowę ze studentami zainicjowała lektura wiersza Życie, przywodzącego na myśl Krótkość żywota Wacława Potockiego. Oksymoroniczne sformułowania: „Nieustająca błyskawiczność. / Wieczność okamgnienia. / Nieśmiertelne krótkotrwanie. / Zawsze obecna przemijalność” precyzują doświadczenia, wypełniające „Koszyk istnienia / Spleciony z miliona nieistnień" (Świrszczyńska 1997: 363) ${ }^{8}$. Wszelkie doznania egzystencjalne podmiotu poddane są prawom zmienności: teraźniejszość cechuje chwilowość, przeszłość stanowi rejestr dokonań, których biegu już zmienić niepodobna, przyszłość zaś w miarę upływu lat się kurczy. Przywilejem wieku dojrzałego poetka czyni zdolność do weryfikowania wszelkich wartości, gdyż spoglądając wstecz na przebytą drogę, człowiek dzięki zdobytemu doświadczeniu

7 Przywołane obrazy poddano pogłębionej interpretacji. W artykule zrezygnowałam jednak z prezentacji tej części wywodu na rzecz oglądu syntetycznego.

8 Wiersze przywołane w artykule pochodzą z tego tomu; w dalszej części artykułu lokalizować je będę poprzez podanie w nawiasie tytułu i strony. 
znacznie głębiej rozumie miłość, przyjaźń, współczucie, samotność. Gotowość do doznawania świata i cieszenia się obfitością jego zwykłości sprawia, że „sekundy istnienia / jak podarki bez ceny" odmierzane zegarem serca nadbiegaja niezauważalnie i oferują "nagie / szczęście istnienia” (Podarki bez ceny: 372). Symbolem spełnienia artystka czyni „wewnętrzne światło" (Cztery nogi są bardzo grube: 375; Jej brzuch: 193; Dytyramb kobiety szczęśliwej: 231-232; Jest we mnie światto: 378; Kontemplacja: 311; Biegam po plaży: 379; Moje pięty i Sokrates: 304; na temat uprawiania przez poetkę jogi zob. Kraskowska 2015: 29-41), „wewnętrzne olbrzymienie” (Oddycham: 310), otwieranie się na przestrzeń metafizycznych uniesień, egzystowanie na granicy widzialnego i niewidzialnego, które umożliwia tytułowe „dojrzewanie do prawdy” istnienia (tamże: 383). Tak waloryzowaną reakcję można uznać za syntezę człowieczeństwa, uwznioślenie jednostkowego trwania w horyzoncie zadziwiającej niezmienności bytu (Dusza i ciało na plaży: 376; Radosna: 377; Jutro będa mnie krajać: 394-395; szerzej na ten temat zob. Dubas 2004: 131-157).

Jako kontekst malarski studenci większością głosów wybrali dwa obrazy: Gerrita Dou Staruszkę czytajaca Biblię (około 1630, Rijksmuseum, Amsterdam) oraz Drzemiaca staruszkę Nicolaesa Maesa (około 1655, Królewskie Muzea Sztuk Pięknych w Brukseli). Na obu płótnach seniorki czytają święte księgi. Lektura ta pozwala szukać odpowiedzi na pytania o sens człowieczego bytu, pomaga w uchwyceniu dystansu niezbędnego do rozpatrywania różnorodnych zagadnień w perspektywie wartości fundamentalnych. Dodajmy, że staruszka pędzla Maesa skupiona jest na Księdze Amosa z przepowiednią zagłady jako konsekwencją grzechu. Takie usytuowanie rozważań (co sugeruje także widoczna na obrazie klepsydra) służy podkreśleniu z jednej strony praw przemijania, z drugiej zaś zawiera naukę - w miarę upływu lat mamy coraz mniej czasu, dlatego nie możemy go tracić z błahych powodów. Dary życia należy właściwie pożytkować. W tym miejscu warto jeszcze wspomnieć, że malarskie (podobnie jak literackie) przedstawienia starszych kobiet jako mędrczyń należą do rzadkości. Rola mędrca (inne odmiany tego wizerunku to: król, władca, Bóg, naukowiec) zarezerwowana była dla mężczyzn.

W perspektywie ponadczasowej lokować wypada również namysł nad kresem istnienia ${ }^{9}$. Strach przed umieraniem przynależy bowiem do właściwych dla człowieczego bytu doznań. Mimo cywilizacyjnego postępu ludzie nie znaleźli sposobu, by oswoić to, co związane jest z nieistnieniem czy istnieniem w innym

9 Rozważania te warto byłoby pogłębić o widoczny w wierszach kontekst biograficzny i przywołać nieżyjących rodziców poetki. Ze względu na ramy artykułu kwestię niniejszą jedynie sygnalizuję. 
wymiarze, a więc niewyrażalnym, nieznanym, obcym. Rozważania studentów zainspirowało m.in. pełne dramatycznego napięcia wyznanie Ja mówiącego: „Umieranie / to robota najcięższa / ze wszystkich. / Starzy i chorzy powinni być od niej zwolnieni" (Ja protestuję: 363). Zdolność współodczuwania wynika z empatycznej postawy podmiotu, umiejętności współ-bycia w cierpieniu (Moje cierpienie: 149). Uwagę przyszłych polonistów zwróciło jednocześnie stylistyczne ukształtowanie utworu - o sprawach ostatecznych mówi się w tej lapidarnej narracji językiem nieskomplikowanym, kolokwialnym: umieranie to po prostu robota. Malarską metaforą przemijania uczestnicy zajęć uczynili Ostatni portret matki Daphne Todd (2009). Swój wybór umotywowali słowami Małgorzaty Modrak (2015: 114): „[...] starość i śmierć to bliskie siostry. Nie mogą bez siebie istnieć, bo starość nieuchronnie kończy się śmiercią". Z obrazu, analogicznie jak z przywołanych wierszy Świrszczyńskiej, przemawiają ból, gniew i rezygnacja. Zarówno poetka, jak i malarz zdają sobie sprawę z kruchości ludzkiego bytu.

\section{KOBIETA - NATURA}

Ewokacja cielesności, widoczna w utworach Kobieta mówi rodzqc świat (313) i Pod czarna gwiazda (200), służy podkreśleniu łączności bytu kobiety z Naturą. Symbolicznym upostaciowaniem tej symbiozy staje się cykliczne koło narodzin i śmierci. Baba występuje jako archaiczna, mityczna matka, stwórczyni życia i kresu, zarówno łaskawa i opiekuńcza, jak i okrutna i przerażająca. Dionizyjska bohaterka wierszy Świrszczyńskiej jest chtoniczną Matką Naturą, Boginią Matriarchatu, która dziesięciu przykazaniom przeciwstawia - zdaniem Anny Węgrzyniakowej (1995: 129) - „dziesięć nadludzkich marchwi ognistych: są nimi fetysze płodności, paleolityczne figurki Wenus z Willendorfu i Laussel"10. Intertekstualna rozmowa ponad wiekami, poetycka próba spojrzenia na płeć piękną w perspektywie makrokosmosu, a zatem uniwersalnej, wiecznej, uznana została przez przyszłych polonistów za ważną także w XXI wieku próbę „oswajania" przez kobiety miejsc dostępnych w przestrzeni międzyludzkiej. Powstałe w paleolicie wapienne dzieła (rzeźba i płaskorzeźba) pomalowane są czerwoną ochrą, która symbolizuje siły witalne oraz krew. Oba przedstawiają nagie kobiety z wydatnymi biustami, rozrośniętymi brzuchami i krótkimi nogami o silnie

10 Figurkę Wenus z Willendorfu odkrył archeolog Joseph Szombathy w 1908 roku podczas prowadzenia prac drogowych w Austrii. Powstała około 22000 - 24000 roku p.n.e. Znajduje się w Naturhistorisches Museum w Wiedniu. Rzeźbę Laussel znalazł psychiatra Jean-Gaston Lalanne w 1911 roku w Akwitanii. Było tam jeszcze pięć fragmentów jednej płaskorzeźby: cztery kobiety i jednego mężczyzny, prawdopodobnie rzucającego oszczepem. Obecnie znajduje się w Musée d'Aquitaine w Bordoux. 
rozwiniętych udach (cechy te uznawano za atrybuty płodności kobiety-matki) ${ }^{11}$. Pierwsza, niższa figurka $(11 \mathrm{~cm})$ wyróżnia się ponadto detalami - ozdobną fryzurą lub nakryciem głowy złożonym z siedmiu rzędów form przypominających drobne loczki oraz wątłymi, złożonymi na biuście rękoma, których większość podobnych statuetek jest pozbawiona. Druga, większa $(43 \mathrm{~cm})$, trzyma w ręku róg żubra (symbol księżyca) z trzynastoma nacięciami, których liczbę interpretuje się jako ilość kobiecych cykli menstruacyjnych w ciągu roku słonecznego, mających także związek z liczbą miesięcy księżycowych.

Świrszczyńska, podobnie jak pradawni artyści, to co nadmierne, obfite i przelewające się w opinii studentów konotuje pozytywnie. W ten sposób kultywuje somatyczność, przypisywaną kulturowo kobiecości, a przez to nadaje dodatkową wartość cielesności, nobilituje ją, docenia elementy marginalizowane, tabuizowane czy wręcz rugowane z przestrzeni publicznej. Wreszcie ukazuje dwoistą rolę kobiety - jest ona, co prawda, dawczynią życia, ale życia skończonego, zespala pierwiastek natalny i tanatalny ${ }^{12} \mathrm{w}$ całości istnienia. Poetka konsekwentnie podkreśla rytm przekazywanego z pokolenia na pokolenie córkom przez matki bólu miesiączkowania, rodzenia i przekraczania kulturowych schematów narzuconych przez świat patriarchalny. W syntetycznym skrócie wspomnianą kwestię, dostępną kobiecie nie tylko u schyłku egzystencji, wyraża jedna $\mathrm{z}$ bohaterek: „Urodzone pod czarną gwiazdą / urodziłyśmy / świat” (Pod czarna gwiazdą: 200). Poród w wymiarze kosmogenicznym czyni twórczyni - na co zwrócili uwagę uczestnicy zajęć - ogniwem jedności kobiet i upomina się o docenienie fundamentalnej roli, jaką odgrywa matka, dając początek istnieniu.

Zakończeniem tej fazy rozważań była refleksja dotycząca autotematycznej wypowiedzi stanowiącej credo artystyczne Świrszczyńskiej: „Mam im powiedzieć, / po co się urodzili, / po co istnieje, / potworność zwana życiem” (Spotkanie autorskie: 365$)$. Wnętrze poetki, mimo prywatnych wątpliwości, przekształcone zostało w swoiste medium, „zdolne - co zaakcentowali studenci słowami Agnieszka Czyżak (2018: 153) - wyrazić specyfikę doświadczenia ludzkiego, jednostkowego, ale i otwierającego się na przestrzeń wszechświata oraz perspektywę kosmiczną".

11 Inspirację dla takich wyobrażeń mogły stanowić pierwotne strażniczki ogniska, które dzięki małej ilości ruchu oraz dobremu odżywianiu mogły w czasach ogólnego niedoboru jedzenia pozwolić sobie na odkładanie zapasów tkanki tłuszczowej, symulującej brzemienność kojarzoną z płodnością.

12 Podobne ujęcia widoczne są w liryce Małgorzaty Hillar (1967). 


\section{WOBEC SPOŁECZNEGO WYKLUCZENIA}

Lekturę wierszy Świrszczyńskiej wzbogaciliśmy namysłem nad stereotypowym postrzeganiem seniorek w przestrzeni publicznej. Truizmem jest stwierdzenie, że utrata społecznej ważności przypada dla kobiety mniej więcej w momencie wygasania zdolności rozrodczych. Strach przed śmiercią za życia sprawia niejako instynktowne ukrywanie wieku. „Mężczyzna - jak podpowiada Simone de Beauvior (2007: 634) - starzeje się stopniowo, kobieta zostaje nagle odarta z kobiecości; w młodym stosunkowo wieku traci urok erotyczny i płodność, które były jedynym usprawiedliwieniem jej istnienia w oczach społeczeństwa i w jej własnych oraz jedyną szansą szczęścia”.

W czasie zajęć zwróciliśmy uwagę na liczne bohaterki kreacji artystycznej Świrszczyńskiej, które doświadczają inkluzji. Używając Goffmanowskiej metaforyki, uznaliśmy, że poetka pozwala niczym suflerom obserwować „siostry z dna”: stare wariatki, żebraczki, macochy, kobiety otyłe (Siostry z dna: 183; Chtopka: 184; Przebudzenie: 184), dla których ludzkość wymyśliła „najbardziej obelżywe słowa świata" (Stara kobieta: 199). Kwintesencję ich bytu funduje przekonanie o „skradzionym", niemożliwym do odzyskania życiu (Dowiedziała się: 186). Wiedzę tę zdobywają niejako mimochodem po wykonaniu szeregu prozaicznych czynności, gdy wreszcie na chwilę przysiadają w pokoju podczas niedzielnego popołudnia. Ascetyczny zapis intymnego momentu odkrycia własnej przemijalności wyraża jedynie ból i rezygnację. Zapomniane, są jednak zdolne do zamanifestowania swojej niezgody wobec bezdusznej obojętności otoczenia. Ich uosobieniem jest uciekinierka z domu opieki społecznej, która „włóczy się ulicami, polami, / krzyczy, śpiewa, klnie / plugawo”, artykułując ukryty „w kościanym relikwiarzu czaszki / bunt" (Bunt: 183). Zaakcentowaliśmy, że współczesny świat kobiety $\mathrm{w}$ jesieni egzystencji spycha na margines, wyklucza z codzienności. Przynależą im jedynie łzy, które z litością „głaszczą starą twarz”, pozwalając „utulić się / w płakaniu / jak w gnieździe" ( $\left.\_z y: 144\right)$. Twórczyni stanowczo przypomina o ich prawie do godności, akceptacji, miłości i samorealizacji. Bezduszne pytanie żon swojego męża, po co żyją stare kobiety, bohaterka jednego z wierszy pointuje lapidarną odpowiedzią: „Mój mąż / nie zapytał mnie jeszcze o to. / On wie, że stare kobiety / Jedzą tak niewiele" (Mtode żony mojego męża: 129).

Niezgoda, rozpacz, maskowany sarkazm i drwina - jak zasugerowali przyszli nauczyciele - stanowią tkankę poetyckiej materii Spojrzeń, będących wnikliwą imitacją stygmatyzującego dyskursu społecznego. „Poetka ekstremalizmu estetycznego i etycznego" (Pieńkosz 1985: 21) protestuje przeciw powszechnej pogardzie okazywanej starym kobietom. Bólem przesiąknięty jest obraz, gdy młodzi chłopcy mijaną „staruszkę w okamgnieniu / rozdeptali [...] jak robaka / 
spojrzeniami” (Spojrzenia: 191). Ciało, pozbawione atrakcyjności na skutek procesów starzenia, jawi się jedynie dokuczliwą i niepożądaną materią, rodzi traumatyczne doznanie samotności, sytuuje zatem bohaterki po stronie abiektu, który - jak wiadomo - nie ma miejsca w symbolicznej reprezentacji. Sytuacja wywołuje drastyczne słowa: „Mówię do swego ciała: / Ty ścierwo, boisz się bólu i głodu, / boisz się przepaści. / Ty głuche, ślepe ścierwo - mówię / i pluję w lustro" (Mówię do siebie: ty ścierwo: 314). Jednostkowe uczucia strachu przed degradacją fizyczną i związanymi z nią konsekwencjami, sytuowanymi w perspektywie codziennego funkcjonowania, autopostrzegania siebie wobec niechcianej metamorfozy cielesnej (estetyka) i duchowej (ograniczenia natury mentalnej), wyrażone opresyjnym kolokwializmem, zamykającym przyszłość, uznane zostały jednocześnie za ważny gest twórczyni, która w ten sposób próbuje otworzyć drogę do refleksji nad lingwistyczną konceptualizacją sędziwych lat seniorek w społecznej praktyce. Celem pogłębienia dyskursu z przyszłymi nauczycielami sięgnięto po doświadczenia zwykłe, przekazy medialne, inne teksty kultury, podejmujące wspomnianą tematykę. Stanowisko Świrszczyńskiej włączono tym samym do współczesnego dyskursu o hegemonii młodości, tabuizującej ostatni etap ziemskiej drogi człowieka.

Kontekstem malarskim, który towarzyszył dyskusji, studenci uczynili trzy obrazy: Głowa starej wieśniaczki Pietera Bruegela (1564, Stara Pinakoteka, Monachium), Portret regentek domu staruszek w Haarlemie Franza Halsa (około 1533, Frans Hals Museum, Haarlem) oraz Vanitas (Marność; tytułowany także: Stara kobieta przed lustrem) Bernarda Strozziego (1615, Muzeum Sztuk Pięknych im. Aleksandra S. Puszkina, Moskwa).

Dzieło niderlandzkiego malarza wyraża właściwą Świrszczyńskiej dążność do indywidualizowania przeżyć bohaterek przy jednoczesnej umiejętności wpisywania tego, co jednostkowe w perspektywę ogólnoludzką. Poetka, niczym szesnastowieczny twórca, kilkoma trafnymi pociągnięciami uzyskuje głębię postaci, trafnie podkreśla jej odmienność i typowość zarazem. Halsowskie regentki to z kolei kwintet, który wygrywa dźwięki i ostre, piskliwe, miękkie i rozlewne melodie: od smutku i współczucia, przez niechęć i obawę, po strach i odrazę. Ich starość jest samotna, zapomniana, naznaczona powykręcanymi palcami u żylastych dłoni, wystającymi z białych mankietów, a także zmarszczkami, których nie da się „wyprasować”. Cechą wspólną samotności kobiet są wąskie usta oraz grymas smutku, który na trwałe uobecnił się w rysach ich twarzy, a dodatkowo żałosne i puste spojrzenie. W podobny sposób przyszli poloniści zinterpretowali wizję Strozziego. Kobieta szukająca w lustrze minionego piękna - według ich opinii - przywołuje skojarzenie z mottem: memento senescere („pamiętaj, że się zestarzejesz") (szerzej na ten temat zob. Eco 2007: 159). 
W liryce Świrszczyńskiej, zdaniem uczestników zajęć, nie ma jednak żadnego butwienia, murszenia, boleści czy melancholii. Poetka zupełnie inaczej rozkłada akcenty. Schyłek bytu wiąże z doprawdy imponującą - może nawet stoicką - akceptacją tego, co oferuje zwykły dzień: krzątactwem, kopaniem ziemniaków, grabieniem siana, praniem, plażowaniem. Studenci, kierując się spostrzeżeniami Urszuli Tabor (2009: 37), uznali, że podobną wymowę mają obrazy staruszek pochłoniętych wykonywaniem codziennych zajęć: Kobieta smażaca jajka Diego Velazqueza (1618, National Gallery of Scotland, Edynburg) czy Stara kobieta podlewajaca kwiaty Gerrit Dou (1660-1665, Muzeum Historii Naturalnej, Wiedeń).

\section{KOBIETA I CIAŁO}

Świrszczyńska nie poprzestaje na rekonstruowaniu wykluczającego starość spojrzenia. Ukazuje kobietę jako istotę aktywną, spragnioną życia, otwartą na zmiany, poszukującą harmonii. Korporalna formuła kobiecości, wpisana w język jej liryki, stanowi wyzwanie wobec wytyczonej przez wieki tradycji, w której wszystko, co cielesne - jak zauważa Anna Nasiłowska (2004: 297) - „musi być niższe i w rezultacie zaprzeczone, odrzucone, przeciwstawione uwznioślonej duchowości". Rewaloryzacja ciała jawi się polemicznym głosem z negatywną stereotypową konceptualizacją starości. Twórczość Świrszczyńskiej studenci słusznie włączyli do afirmatywnego nurtu starości (por. Legeżyńska 2009: 326; zob. także: Legeżyńska 1999). Znaczna część wierszy przynosi bowiem pozytywny zapis schyłkowych lat życia kobiety optymistycznie, euforycznie nastawionej wobec rozkoszy, jakich może dostarczyć jej ciało (fizyczne pożądanie mężczyzny, potrzeba zaspokojenia seksualnego niezależnie od wieku). Tak waloryzowany czas seniorki nie zamyka, lecz otwiera na nowe, nieznane wcześniej bądź niedostatecznie rozpoznane doznania, uczucia i emocje ${ }^{13}$. Na zajęciach przywołano wiersze Świrszczyńskiej, w których bohaterka, choć ma 60 lat, podejmuje przerwany niegdyś dialog z miłością - uczuciem nadającym sens istnieniu (Biłam głowq o ścianę: 333), zjada „z zachwytem / swoją kromkę szczęścia”, przeżywa „Największą miłość swojego życia” (Z twoimi rękami na szyi: 388). Jej byt wyznacza rytm intymnych uniesień: „Chodzi z miłym pod rękę, / Wiatr rozwiewa ich siwe włosy", mimo że jej dzieci nazywają ją "starą wariatką" (Największa miłość: 195). Starej Babie odmówiono bowiem - jak powiada Miłosz - sympatii, wzbudza ona wrogość, ponieważ jej seksualność od lat poddana jest w znacznie większym stopniu społecznemu ostracyzmowi niż erotyczne porywy Starych

\footnotetext{
13 Podobne tony zawarte są w dziennikach Świrszczyńskiej (2019).
} 
Mistrzów ${ }^{14}$. Korzeni takiej postawy szukano w antyku, który - jak pisze Georges Minois (1995: 111) - stare ciało kobiece, będące „w młodości symbolem piękna”, traktował jako "symbol najwyższej brzydoty, istną zniewagę, rzuconą zmysłom”.

Współobecność z partnerem nie oznacza jednak współ-przenikania. Nawet największe uczucie w poezji Świrszczyńskiej wiąże się z niemożnością wzajemnego poznania. Światy: męski i żeński - choć komplementarne - są jednocześnie osobne. Bohaterka wierszy poznała samotność bez kogoś i samotność we dwoje. Odkryła też samotność waloryzowaną jako niemożność bycia z kimś do końca, zobaczenia się w innym człowieku. Późna miłość wiąże się ponadto z wyrażoną expressis verbis obawą przed odsłonięciem mankamentów niedoskonałego już ciała: „To jest moje nagie ciało. / Ty je podobno lubisz, / ja nie mam powodu (Grube jelito: 222).

W tej części zajęć studenci sięgnęli po dwie prace malarskie: Dziada i babę Tadeusza Makowskiego (około 1930, Muzeum Narodowe w Warszawie) oraz autoportret Alice Neel (1980, National Portrait Gallery, Waszyngton). Polski artysta, znany zwykle z przedstawień dzieci, tą samą kreską - upodobniającą jego obrazy do dziecięcych malunków - stworzył portret starej pary. Staruszkowie siedzą obok siebie z założonymi rękami, mężczyzna pali fajkę. Nie obejmują się, nawet nie patrzą na siebie. Wydaje się jednak, że uśmiech i spokój emanujący z ich twarzy potwierdzają wzajemną bliskość, zażyłość, chęć wspólnego przeżywania świata. Obraz amerykańskiej artystki studenci potraktowali jako manifest kobiecej starości. Mówili o obojętnym wyrazie twarzy Neel oraz jej dążeniu do uchwycenia prawdy przemijania. Rozebrana, stateczna, starsza pani w okularach uświadamia, że ciało podlega fizycznej degradacji, ale nie znika.

\section{ZAKOŃCZENIE}

Świat starych kobiet jest dla Świrszczyńskiej pełną rozmaitych historii opowieścią o życiu, zaproszeniem do refleksji o ich egzystencjalnej empirii, wrażeniach metafizycznych, transcendencji kondycji człowieka i poszukiwaniach jego substancjalnej istoty. Ich ciała mówią własnym językiem. Każda blizna, rozstęp, deformacja czy dodatkowa zmarszczka potwierdzają wcześniejsze doznania: radości i smutki, chwile dobre i pełne udręki, które pozostawiły po sobie trwały ślad. Pozbawiona żalu, bliska niekiedy amor fati, pochwała pełni bytu staje się

14 O stosunku społeczeństwa do Świrszczyńskiej poetycko wyraził się Miłosz (2011: 1070): „Kiedy zobaczyłem Ciebie raz ostatni, / Zrozumiałem dlaczego ciebie nie lubili, / Ani twojej poezji. Z tą twoją białą grzywą / Tylko jeździć na miotle, mieć diabła za kochanka, / A ty jeszcze się obnosiłaś / Z filozofią wielkiego palca u nogi, / Żeńskiej szpary, pulsu, grubego jelita". 
potwierdzeniem niesłabnącej z wiekiem aktywności kobiet, codziennego zaangażowania w każdy, nawet najdrobniejszy przejaw trwania. Zwraca uwagę stoickie podejście do kruchości bytu, manifestacja uroków wieczoru istnienia, empatia, prowokacja, odkrywcze przekraczanie obyczajowego i społecznego tabu, akceptacja korporalnych zmian oraz mądrości wspartej doświadczeniami przeszłości.

Hojnie obdarowana przez los bohaterka wierszy formułuje ważną dla odbiorcy deklarację o proteuszowej naturze ludzkiego istnienia - byłam „piękna i szpetna, / mądra i głupia, / bardzo szczęśliwa i bardzo nieszczęśliwa" (Jutro będa mnie krajać: 394). Optymizmem przepełnione są próby oswajania kresu bytu, „właściwe nazywanie” - jak podpowiada Tomasz Mizerkiewicz (2007: 197-198) - adekwatnych na przemijanie reakcji człowieka, nie tylko przedstawicielek płci pięknej. Starości bohaterek artystycznej kreacji Świrszczyńskiej nie wypełniają narzekania, utyskiwania na zbliżający się kres, nie ma w niej tonów dramatycznych z powodu zbliżającej się śmierci, choć - co oczywiste - pojawia się lęk przed nieznanym i w związku z tym niewyrażalnym w mowie końcem istnienia.

Usytuowanie liryki Świrszczyńskiej w kontekście malarskim pozwoliło na pogłębienie empatycznego odbioru wierszy, a także służyło podkreśleniu uniwersalizmu spojrzenia poetki. Jednocześnie włączyło starość kobiet do refleksji senilnej przyszłych polonistów, czyniąc z wypowiedzi twórczyni ważny głos w dyskusji społecznej na temat powszechnie marginalizowanych czy tabuizowanych zagadnień.

\section{BIBLIOGRAFIA}

Beauvoir, S. de (2007). Druga pteć. Warszawa: Wydawnictwo Czarna Owca.

Czyżak, A. (2018). Poetki wobec przemijania. W: J. Grądziel-Wójcik, A. Kwiatkowska, E. Sołtys-Lewandowska (red.), Formy (nie)obecności. Szkice o współczesnej poezji kobiet (s. 149-164). Kraków: TAiWPN Universitas.

Dubas, E. (2004). Starość w perspektywie rozwoju, duchowości i edukacji. Geragogiczny przyczynek do refleksji nad starością i starzeniem się człowieka. W: A.E. Wesołowska (red.), Człowiek i edukacja (s. 131-157). Płock: Wydawnictwo Naukowe NOVUM. Eco, U. (2007). Historia brzydoty. Poznań: Dom Wydawniczy Rebis.

Gajak-Toczek, M. (2012). "Without us dreams couldn't exist". Reflection on several poems from the volume "Wystarczy" [Enough] by Wistawa Szymborska. Pobrane z: http:// socin.mruni.eu/wp-content/uploads/2012/12/E_2012-12-26.pdf [dostęp: 7.10.2019].

Gajak-Toczek, M. (2013). A Few Reflections on Life-passing on the Basis of Works by Tadeusz Różewicz and Czesław Miłosz. Žmogus ir žodis / Man and the Word, vol. 15(2), 76-82.

Gajak-Toczek, M. (2018). Obraz starości w wybranych tekstach literackich na poziomie szkoły średniej. W: E. Chodźko, P. Szymczyk (red.), Literatura i kultura $w$ życiu człowieka - wybrane motywy (s. 161-172). Lublin: Wydawnictwo Tygiel. 
Gajak-Toczek, M., Gala-Milczarek, B. (2015). Człowiek stary w mediach - stereotyp a obraz postulowany. W: M. Karwatowska, B. Jarosz (red.), (Nowe) media. Implikacje kulturowe, językowe i edukacyjne (s. 51-61). Lublin: Wydawnictwo UMCS.

Gajak-Toczek, M., Gala-Milczarek, B. (2017). Edukacja ku starości w kręgu kinematografii polskiej (na wybranych przykładach). W: I. Morawska, M. Latoch-Zielińska (red.), Edukacja polonistyczna wobec przemian kulturowych (s. 209-226). Lublin: Wydawnictwo UMCS.

Hillar, M. (1967). Czekanie na Dawida. Warszawa: Wydawnictwo Iskry.

Ingbrant, R. (2018). Kobiecy antyświat w poezji Świrszczyńskiej. W: J. Grądziel-Wójcik, A. Kwiatkowska, E. Sołtys-Lewandowska (red.), Formy (nie)obecności. Szkice o wspótczesnej poezji kobiet (s. 261-270). Kraków: TAiWPN Universitas.

Kłakówna, Z.A. (2016). Akademicki podręcznik myślenia o zawodzie szkolnego polonisty. Język polski. Wyktady z metodyki. Kraków: Oficyna Wydawnicza Impuls.

Kraskowska, E. (2015). Poetka i joga. W: J. Grądziel-Wójcik, J. Kaniewski, K. Kwiatkowska, T. Umerle (red.), Laboratorium poezji kobiecej XX wieku (s. 29-41). Poznań: Wydawnictwo Nauka i Innowacje.

Kwiatkowski, J. (1971). Notatnik. Poezja, nr 7, 100-102.

Kwiatkowski, J. (1995). Baba potęgą jest i basta. W: tegoż, Magia poezji (O poetach polskich XX wieku) (s. 373-376). Kraków: Wydawnictwo Literackie.

Legeżyńska, A. (1999). Gest pożegnania. Szkice o poetyckiej świadomości elegijno-ironicznej. Poznań: Poznańskie Studia Polonistyczne.

Legeżyńska, A. (2009). Od kochanki do psalmistki. Sylwetki, tematy i konwencje liryki kobiecej. Poznań: Wydawnictwo Poznańskie.

Miłosz, C. (1996). Jakiegoż to gościa mieliśmy. O Annie Świrszczyńskiej. Kraków: Społeczny Instytut Wydawniczy Znak.

Miłosz, C. (2011). Tłumacząc Annę Świrszczyńską na wyspie Morza Karaibskiego. W: tegoż, Wiersze wszystkie (s. 1070-1071). Kraków: Społeczny Instytut Wydawniczy Znak.

Minois, G. (1995). Historia starości: od antyku do renesansu. Warszawa-Gdańsk: Oficyna Wydawnicza Volumen, Wydawnictwo Marabut.

Mizerkiewicz, T. (2007). Nic śmiesznego. Szkice o komizmie w literaturze polskiej XX i XXI wieku. Poznań: Wydawnictwo Naukowe Uniwersytetu im. Adama Mickiewicza.

Modrak, M. (2015). Obraz kobiecej starości w literaturze i sztuce. Poznań: Wydawnictwo Naukowe Silva Rerum.

Nasiłowska, A. (2004). Tożsamość kobieca w poezji polskiej XX wieku: między androgynicznością a esencjalizmem. W: W. Bolecki, R. Nycz (red.), Narracja i tożsamość (II). Antropologiczne problemy literatury (s. 282-299). Warszawa: Instytut Badań Literackich PAN.

Olszański, G. (2012). Taka sama w środku. O tomie Jestem baba Anny Świrszczyńskiej. W: tegoż, Apelacje. Szkice o literaturze i przygodach jej twórców (s. 36-62). Mikołów: Instytut Mikołowski.

Pieńkosz, K. (1985). Anna Świrszczyńska. Literatura, nr 1, 20-21.

Stapkiewicz, A. (2014). Ciało, kobiecość i śmiech w poezji Anny Świrszczyńskiej. Kraków: TAiWPN Universitas. 
Pobrane z czasopisma Annales N - Educatio Nova http://educatio.annales.umcs.pl Data: 26/04/2023 16:56:14

Stawowy, R. (2004). „Gdzie jestem ja sama”. O poezji Anny Świrszczyńskiej. Kraków: Universitas.

Stefaniak-Hrycko, A. (2006). Stare kobiety: problemy z rolą i tożsamością. Teksty Drugie, nr 3, 202-210.

Świrszczyńska, A. (1997). Poezja. Warszawa: PIW.

Świrszczyńska, A. (2019). Jeszcze kocham. Zapiski intymne. Warszawa: Wydawnictwo W.A.B.

Tabor, U. (2009). Metafory starości - interpretacja tematu starości w dziełach malarstwa. Chowanna, t. 2(33), 33-47.

Uryga, Z. (1996). Godziny polskiego. Z zagadnień ksztatcenia literackiego. WarszawaKraków: PWN.

Węgrzyniakowa, A. (1995). „Siwa baba i biega”. Ostatnie wiersze Anny Świrszczyńskiej. W: A. Nawarecki, A. Dziadek (red.), Starość. Wybór materiałów z VII Konferencji Pracowników Naukowych i Studentów Instytutu Nauk o Literaturze Polskiej UŚ (s. 124-136). Katowice: Górnośląska Macierz Kultury.

Wiśniewski, W. (1986). Szukam człowieka. Rozmowy z pisarzami. Poznań: Krajowa Agencja Wydawnicza. 